\title{
Pertumbuhan dan Struktur Umur Kerang Kepah (Meretrix meretrix) di Kampung Nipah Desa Sei Nagalawan Kecamatan Perbaungan Kabupaten Serdang Bedagai
}

\author{
Nafi Sakila ${ }^{*}$, Dinda Ayu Ramadhani ${ }^{a}$, Ani Suryanti ${ }^{b}$ \\ a Manajemen Sumberdaya Perairan, Fakultas Pertanian, Universitas Sumatera Utara, Jl. Prof. A. Sofyan No. 3, \\ Sumatera Utara 20155, Indonesia \\ ${ }^{b}$ Sosial Ekonomi Perikanan, Fakultas Ilmu Kelautan dan Perikanan, Universitas Maritim Raja Ali Haji, Jl. Politeknik Senggarang, \\ Tanjungpinang 29100, Indonesia \\ * Penulis koresponden. Tel.: +62-853-5872-6939 \\ Alamate-mail: sakilanafi@gmail.com
}

Diterima (received) 17 September 2017; disetujui (accepted) 17 Desember 2017; tersedia secara online (available online) 18 Desember 2017

\begin{abstract}
Sei Nipah has enormous potential for natural resources. Natural resources that serve as the main livelihood in fulfilling daily needs in Kampung Nipah is shellfish. Shellfish (M. meretrix) is one of the shells that many interested by the surrounding community. The purpose of this research is to know growth parameter and age group of shellfish (M. meretrix) in Kampung Nipah. The sampling technique was done randomly (simple random sampling). Sampling time is done at low tide. Sampling was conducted in March - May 2017. The results showed differences in the length of different shells each month. The size group of shellfish (M. meretrix) found only one size group during the three months of the study. Analysis of shellfish growth parameters based on data of long frequency distribution showed length of infiniti $(\mathrm{L} \infty) 33,10 \mathrm{~mm}$ and growth growth $(\mathrm{K})$ that was 1,21 per month. Von Bertalanffy Growth Parameters $\mathrm{Lt}=33.1\left(1-\mathrm{e}^{[-1.21(\mathrm{t}+0.12)]}\right)$ Long infiniti size is seen the growth of shellfish shells can no longer be worked Shells reach maximum length at the age of 13 months with a shell length of $33.10 \mathrm{~mm}$. The youthful shells have rapid growth and as age increases, when it reaches old age the rate of growth will slow even.
\end{abstract}

Keywords: growth; age group; shellfish; Nipah Village

\begin{abstract}
Abstrak
Sei Nipah memiliki potensi yang sangat besar akan sumber daya alam. Sumber daya alam yang dijadikan sebagai mata pencarian utama dalam memenuhi kebutuhan sehari-hari di Kampung Nipah adalah kerang. Kerang kepah ( $M$. meretrix) merupakan salah satu kerang yang banyak diminati oleh masyarakat sekitar. Tujuan dari penelitian ini adalah untuk mengetahui parameter pertumbuhan dan kelompok umur kerang kepah (M. meretrix) di Kampung Nipah. Teknik pengambilan sampel dilakukan secara acak (simple random sampling). Waktu pengambilan sampel dilakukan pada saat surut. Pengambilan sampel dilakukan pada bulan Maret - Mei 2017. Hasil penelitian menunjukkan bahwa jumlah distribusi panjang kerang kepah berbeda setiap bulan. Kelompok ukuran kerang kepah (M. meretrix) hanya ditemukan satu kelompok ukuran selama tiga bulan penelitian. Analisis parameter pertumbuhan kerang kepah berdasarkan data sebaran frekuensi panjang menunjukkan nilai ukuran panjang infiniti $(\mathrm{L} \infty)$ 33,10 mm dan nilai koefisien pertumbuhan $(\mathrm{K})$ yaitu 1,21 per bulan. Parameter pertumbuhan Von Bertalanffy $\mathrm{Lt}=33,1\left(1-\mathrm{e}^{[-1,21}\right.$ $\left.{ }^{(t+0,12]}\right)$. Ukuran panjang infiniti memperlihatkan bahwa pertumbuhan cangkang kerang kepah sudah tidak dapat dicapai lagi. Kerang kepah mencapai panjang maksimum pada umur 13 bulan dengan panjang cangkang 33,10 mm. Kerang yang berumur muda memiliki pertumbuhan yang cepat dan seiring dengan pertambahan umur, ketika mencapai umur tua maka laju pertumbuhannya akan lambat bahkan cenderung statis (tetap).
\end{abstract}

Kata Kunci: pertumbuhan; kelompok umur; kerang kepah; Kampung Nipah 


\section{Pendahuluan}

Satu-satunya daerah di Desa Sei Nagalawan yang berbatasan langsung dengan laut adalah wilayah Sei Nipah. Sei Nipah memiliki potensi yang sangat besar akan Sumberdaya alamnya. Sumberdaya alam yang ditemukan di ekosistem tersebut memiliki banyak jenis dan keanekaragaman organisme. Berdasarkan Penelitian Simatupang dkk. (2017) bahwa makrozoobentos yang ditemukan di Muara Sungai Nipah berjumlah 28 spesies yang digolongkan ke dalam filum Molusca. Dari semua jenis makrozoobentos yang telah dikelompokkan terdapat 2 kelas yaitu Bivalvia dan Gastropoda. Kelas Bivalvia terdiri dari 3 Ordo yaitu Arcida, Mytiloida, dan Veneroida. Organisme yang dijadikan sebagai mata pencarian utama dalam memenuhi kebutuhan sehari-hari di Kampung Nipah salah satu nya adalah kerang.

Kerang kepah (M. meretrix) merupakan salah satu kerang yang banyak diminati oleh masyarakat sekitar. Masyarakat memanfaatkan kerang kepah sebagai salah satu sumber daya andalan di Kampung Nipah. Desa Sei Nagalawan merupakan penggabungan dua desa yang pernah ada sebelumnya yakni Desa Nipah dan Desa Nagalawan. Proses penggabungan ini semakin menambah luas wilayah Desa Sei Nagalawan. Karena luasnya wilayah maka Desa Sei Nagalawan kemudian dibagi menjadi tiga dusun. Sei Nagalawan menyimpan sumberdaya alam berbasis pesisir dan laut yang sangat luar biasa. Hal ini dapat dilihat bahwa keberadaan pantainya tidak hanya mampu menghidupi masyarakat yang tinggal di wilayah Sei Nagalawan. saja, akan tetapi termasuk masyarakat di desa tetangga seperti Lubuk Bayas, Lubuk Rotan, Naga Kisar dan lain sebagainya. Dari pernyataan tersebut, kita dapat mengetahui bahwa kerang kepah sangat diminati masyarakat sekitar.

Tingginya kegiatan/aktivitas masyarakat terhadap kerang kepah sebagai pemenuhan kebutuhan ekonomi dan kebutuhan pemenuhan gizi tentunya akan berpengaruh pada kelangsungan hidupnya di masa yang akan datang, sehingga perlu dilakukan penelitian. Serangkaian penelitian yang berkaitan dengan keberadaan kerang kepah seperti aspek biologi maupun aspek ekologinya dari penelitian tersebut dapat dijadikan dasar pengelolaan kerang kepah. Salah satu aspek paling penting yang perlu diteliti adalah aspek biologi kerang kepah yaitu dari aspek pertumbuhan dan struktur umur sangat perlu diketahui untuk menduga besarnya populasi. Bahtiar dkk. (2015) menyatakan bahwa Bila pertumbuhan populasi tidak dapat mengimbangi laju kematian karena penangkapan maka akan menyebabkan adanya lebih tangkap yang ditandai dengan banyaknya kerang yang berukuran kecil.

Tujuan dari penelitian ini adalah untuk mengetahui pertumbuhan kerang kepah ( $M$. meretrix) menggunakan Von Bertalanffy dan menganalisis kelompok umur kerang kepah ( $M$. meretrix). Manfaat dari penelitian ini adalah sebagai informasi kepada masyarakat umum, khususnya bagi pengembangansumberdaya serta rekomendasi kepada Stakeholder dalam membuat kebijakan tentang pemanfaatan sumberdaya kerang kepah (M. meretrix) di Kampung Nipah secara lestari dan berkelanjutan.

\section{Metode Penelitian}

Penelitian ini dilaksanakan selama tiga bulan (3 bulan) yaitu bulan Maret-Mei 2017 di Kampung Nipah Desa Sei Nagalawan Kecamatan Perbaungan Kabupaten Serdang Bedagai. Lokasi penelitian dapat dilihat pada Gambar 1.

Pengambilan sampel kerang kepah dilakukan secara acak (simple random sampling), sehingga dapat mewaliki ukuran-ukuran kepah yang tertangkap. Kepah yang tertangkap dikumpulkan selama periode penelitian di lapangan. Pengambilan sampel ini dilakukan pada saat surut terendah yang dilakukan secara manual. Pengambilan sampel ini dilakukan sekali dalam sebulan selama tiga bulan penelitian. Wiharyanto dkk. (2013) menyatakan bahwa pengambilan sampel sebanyak $10 \%$ sudah dapat mewakili jumlah keseluruhan populasi kerang kepah. Pengambilan sampel kereang dari suatu populasi dilakukan dengan pertimbangan tertentu. Dalam pemilihan bentuk dan ukuran sampel kerang dilakukan secara random dimuai dari ukuran terkecil hingga ukuran terbesar. Pengukuran kerang kepah yang dilakukan yaitu pengukuran panjang, lebar, dan tebal kepah menggunakan jangka sorong (Calliper) dengan ketelitian 0,02 mm (Fauzi dan Rusliadi, 2011), Selanjutnya parameter yang diamati pada penelitian ini meliputi suhu, salinitas, $\mathrm{pH}$. Pengukuran parameter suhu, salinitas, $\mathrm{pH}$ dilakukan di lokasi penelitian. 


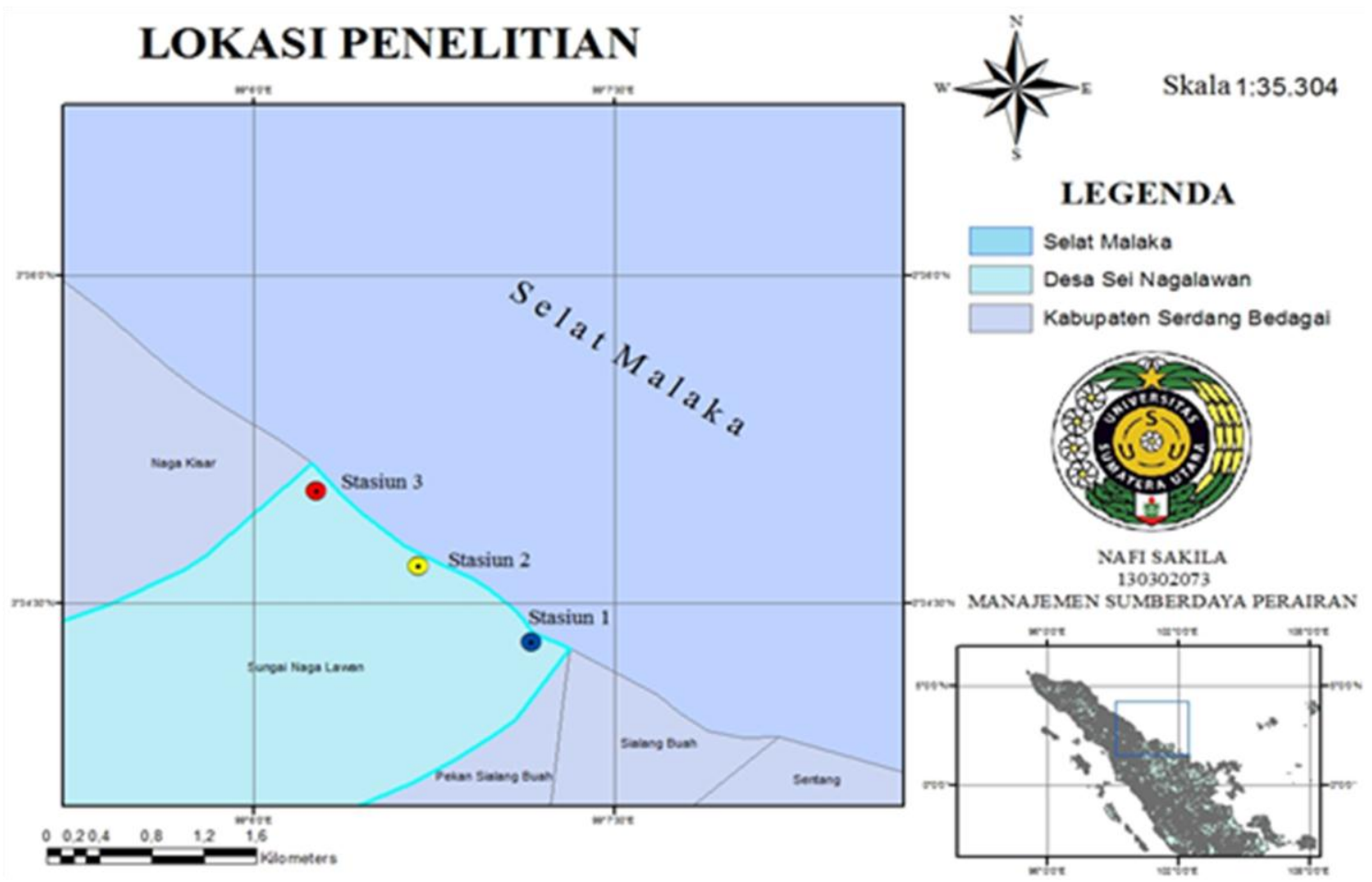

Gambar 1. Lokasi penelitian

\section{Analisis Data}

Data hasil pengukuran tersebut dianalisis secara manual menggunakanbantuan software FISAT II Ver 1.2.2 tahun 2005 yang dikeluarkan oleh FAOICLARM. Analisis data yang dilakukan mencakup sebagai berikut:

\subsection{Distribusi Frekuensi Panjang}

Data ukuran panjang dikelompokan ke dalam kelas-kelas panjang. Pengelompokan kerang ke dalam kelas-kelas panjang dilakukan dengan menetapkan terlebih dahulu "range" atau wilayah kelas, selang kelas dan batas-batas kelas panjang berdasarkan jumlah yang ada. Data diplotkan ke dalam grafik yang menghubungkan antara panjang kerang kepah ada kelas-kelas panjang tertentu dengan jumlah kerang pada kelas panjang tertentu tersebut. Pembagian selang kelas ukuran panjang dilakukan dengan cara $1+3,3 \log N$, sedangkan lebar selang kelas (PmaksimumPminimun) dibagi dengan jumlah selang kelas yang sudah diperoleh sebelumnya (Tamsar, 2013).

Selanjutnya distribusi frekuensi panjang yang telah ditentukan diplotkan dalam sebuah grafik. Dari grafik tersebut dapatterlihat pergeseran distribusi kelas panjang setiap bulannya (Waris dkk., 2014).

\subsection{Distribusi Frekuensi Panjang}

Analisis pemisahan kelompok-kelompok umur berdasarkan ukuran panjang yang dipilih dalam penelitian ini menggunakan metode Bhattacharya. Metode Bhattacharya merupakan salah satu cara grafis untuk memisahkan data sebaran frekuensi panjang ke dalam beberapa distribusi normal. Pemisahan distribusi normal dengan metode Bhattacharya ini dilakukan dengan paket program FiSAT II Versi 1.2.2 (Sparre dan Venema,1999).

\subsection{Parameter Pertumbuhan}

Pendugaan parameter pertumbuhan dilakukan dengan menggunakan rumus pertumbuhan Von Bertalanffy (Sparre dan Venema, 1999), dapat dilihat pada persaman 1 .

$\mathrm{Lt}=\mathrm{L} \infty(1-\mathrm{e}[-\mathrm{K}(\mathrm{t}-\mathrm{t} 0)])$

Selanjutnya penentuan t0 digunakan rumus empiris Pauly (1983) dalam Sparre dan Venema (1999), dapat dilihat pada persamaan 2.

$\log (-\mathrm{t} 0)=0,3992-0,2752(\log \mathrm{L} \infty)-1,038(\log \mathrm{K})$

L $\infty$ adalah panjang maksimum kerang kepah secara teoritis (panjang asimptotik), $\mathrm{K}$ adalah Koefisien laju pertumbuhan (per satuan waktu) 

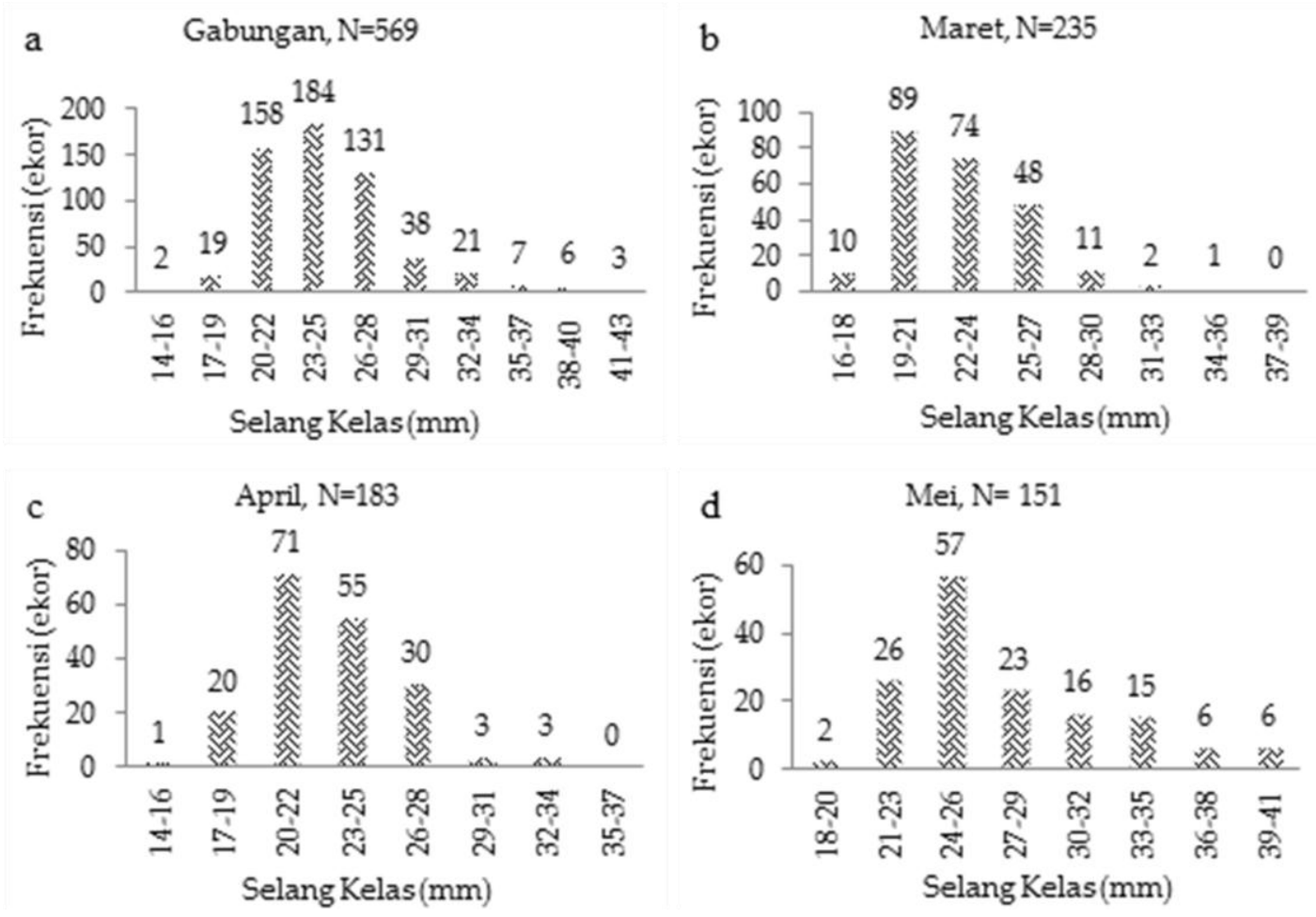

Gambar 2. Sebaran ukuran panjang. a) Gabungan; b) Maret; c) April; dan d) Mei.

dan t0 adalah umur teoritis kerang kepah pada saat panjang total cangkang sama dengan nol.

\subsection{Kualitas Air}

Menurut MNLH (2004) melalui Kepmen LH No. 51 tahun 2004 tentang Baku Mutu Air Laut untuk Biota dapat dlihat pada Tabel 1.

Tabel 1

Kualitas Air

\begin{tabular}{lccl}
\hline \multicolumn{1}{c}{ Parameter } & Satuan & Baku Mutu & Analisis \\
\hline Suhu & ${ }^{\circ} \mathrm{C}$ & $28-32$ & Insitu \\
$\mathrm{pH}$ & - & $7-8,5$ & Insitu \\
Salinitas & \% & alami & Insitu \\
\hline
\end{tabular}

\section{Hasil}

\subsection{Distribusi Frekuensi Panjang}

Hasil perhitungan frekuensi panjang selama tiga bulan didapatkan nilai tertinggi pada ukuran 23 $25 \mathrm{~mm}$ (ukuran sedang), nilai frekuensi panjang terendah didapatkan pada ukuran $14-16 \mathrm{~mm}$ (ukuran kecil) (Gambar 2a).

\subsection{Kelompok Umur}

Berdasarkan hasil analisis kelompok ukuran kerang kepah dengan menggunakan metode Bhattacharya melalui program FISAT. Hasil pengelompokan perbedaan struktur umur yang tidak stabil dapat dilihat dari nilai puncak tertinggi. Nilai puncak tertinggi berada pada bulan mei yaitu 24,66 mm (Gambar 3c). Dan nilai titik puncak terendah berada pada bulan April yaitu 19,35 mm (Gambar 3b), dilanjutkan pada bulan Maret dengan nilai yang tidak terlalu jauh rentang nilainya yaitu 20,29 (Gambar 3a).

\subsection{Parameter Pertumbuhan}

Pendugaan parameter pertumbuhan $(\mathrm{L} \infty)$ panjang asimtotik dan (K) koefisien pertumbuhan kerang kepah (M. meretrix) dapat diduga dari hasil analisis kelompok ukuran panjang dengan menggunakan model pertumbuhan von Bertalanffy melalui analisis program FiSAT II versi 3.0. Hasil analisis parameter pertumbuhan kerang kepah berdasarkan data sebaran frekuensi panjang menunjukkan nilai ukuran panjang infiniti $(L \infty)$ $33,10 \mathrm{~mm}$ dan nilai koefisien pertumbuhan $(\mathrm{K})$ yaitu 1,21 per bulan. Kurva pertumbuhan von Bertalanffy berdasarkan data frekuensi panjang dapat dilihat pada Gambar 4. 

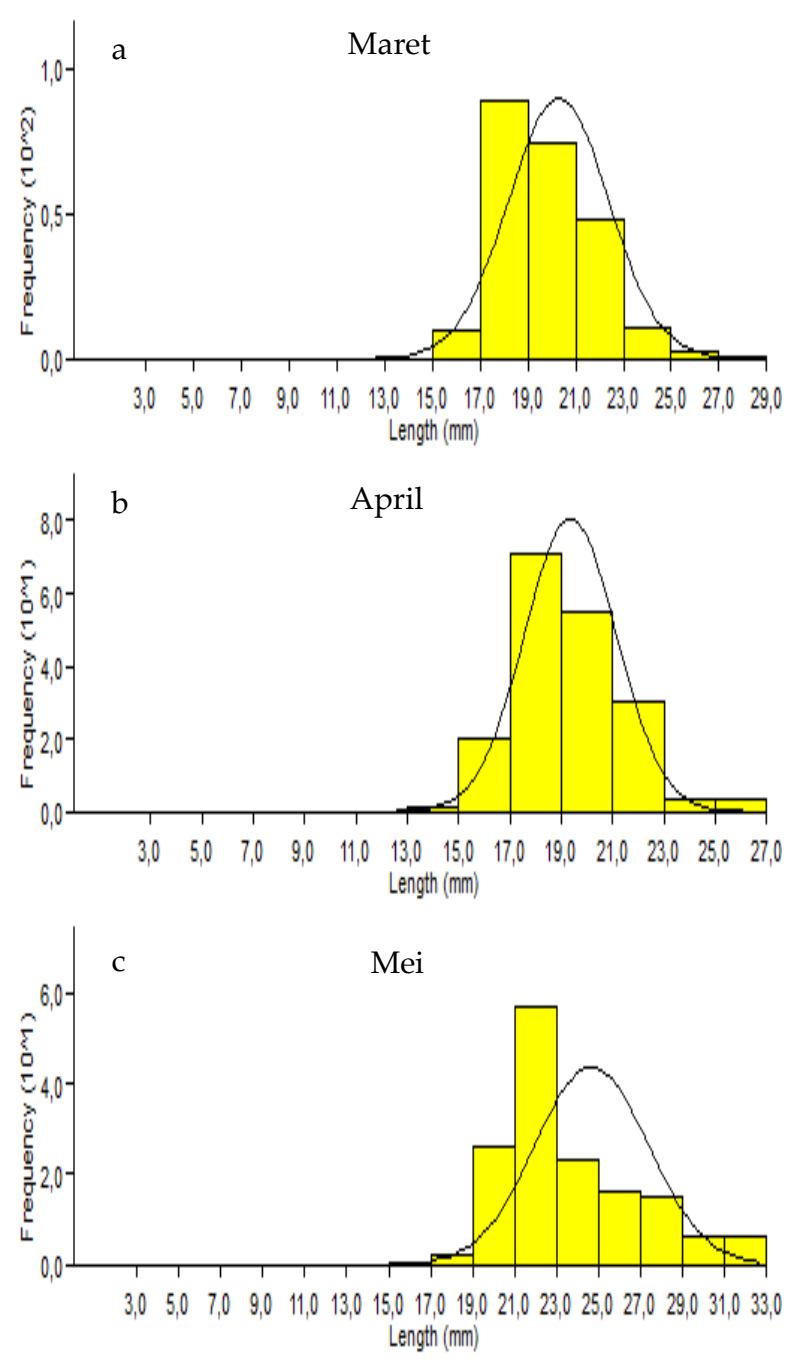

Gambar 3. Kelompok Umur. a) Maret; b) April; dan c) Mei

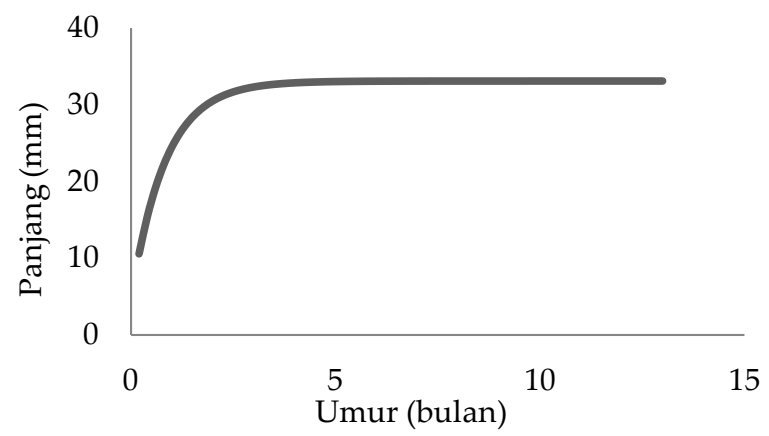

Gambar 4. Kurva pertumbuhan von Bertalanffy

\subsection{Kualitas Air}

Hasil pengukuran parameter suhu selama tiga bulan penelitian mempunyai nilai rata-rata sebesar $30,15^{\circ} \mathrm{C}$. Kisaran suhu tersebut merupakan kondisi normal bagi kehidupan bivalvia. Akbar dkk. (2014) menyatakan bahwa suhu yang sesuai untuk bivalvia berkisar antara $28-31^{\circ} \mathrm{C}$.
Hasil pengukuran salinitas selama tiga bulan penelitian diperoleh nilai rata-rata salinitas perairan di Kampung Nipah Desa Sei Nagalawan yaitu $26,7 \%$ o. Nilai salinitas ini tergolong rendah sehingga berpengaruh terhadap pertumbuhan kerang.

Hasil pengukuran $\mathrm{pH}$ rata-rata selama tiga bulan penelitian diperoleh sebesar 7,4. Pengukuran $\mathrm{pH}$ terendah yaitu pada pengambilan pertama senilai 7,3 sedangkan $\mathrm{pH}$ tertinggi yaitu pada pengambilan ketiga. Hasil pengukuran parameter kualitas air pada pengambilan pertama, kedua dan ketiga dapat dilihat pada Tabel 2.

\section{Pembahasan}

\subsection{Distribusi Frekuensi Panjang}

Perbedaan ukuran tersebut dipengaruhi oleh beberapa faktor yaitu adanya perbedaan lokasi lingkungan, tekanan penangkapan per tiap bulan. Hal ini sesuai dengan pernyataan Komala (2011) perbedaan frekuensi disebabkan antara lain perbedaan lokasi, keterwakilan contoh yang diambil, adanya tekanan penangkapan yang tinggi atau terdapat faktor yang sulit dikontrol seperti keturunan, umur, parasit, dan penyakit. Hal ini sejalan dengan pernyataan Effendi (1997) bahwa perbedaan frekuensi tersebut disebabkan oleh kondisi lingkungan yang kurang optimum, keturunan, jenis kelamin, umur, parasit, makanan, suhu, kualitas air. Jumlah kerang kepah pada ukuran kecil disebabkan oleh tingginya aktivitas masyarakat sehingga dapat mempengaruhi kualitas perairan, dan mengganggu keberlangsungan hidup kerang kepah. Nasrawati dkk. (2017) dan Bahtiar dkk. (2016) menyatakan bahwa kematian alami disebabkan oleh kualitas lingkungan perairan, sehingga kerang tersebut tidak dapat tumbuh pada stadia muda menuju stadia dewasa.

\subsection{Distribusi Frekuensi Panjang}

Perbedaan nilai puncak tersebut disebabkan oleh perbedaan penangkapan masyarakat, sedikit ditemukanya ukuran dewasa yang tertangkap, dikhawatirkan akan dapat menurunkan populasi. Hal ini sejalan dengan pernyataan Bahtiar dkk. (2015) bahwa kondisi populasi tersebut cukup mengkhawatirkan karena tidak ditemukannya stadia tua yang merupakan ukuran yang diambil oleh masyarakat sehingga bila terjadi 
penangkapan kerang maka stadia dewasa yang produktif untuk menghasilkan individu baru akan tertangkap dan populasi ini akan terus mengalami penurunan.

Kelompok ukuran kerang kepah (M. maetrix) dapat dilihat pada Gambar 3 hanya terdapat satu gelombang menandakan satu kelompok umur. Dilaporkan dalam penelitian Tamsar (2013) menunjukkan 2 gelombang bahwa kelompok ukuran kerang $P$. erosa jantan dan betina pada bulan Maret-Mei masing-masing menunjukan dua kelompok ukuran. Hal ini berarti bahwa terdapat dua generasi yang hidup bersama dalam satu waktu.

\subsection{Parameter Pertumbuhan}

Analisis perhitungan parameter pertumbuhan didapatkan nilai ukuran panjang infiniti $\left(L_{\infty} \infty\right) 33,10$ $\mathrm{mm}$ dan koefisien pertumbuhan (K) 1,21. Ukuran panjang infiniti memperlihatkan bahwa pertumbuhan cangkang kerang kepah sudah tidak dapat dicapai lagi. Kerang kepah mencapai panjang maksimum pada umur 13 bulan dengan panjang cangkang 33,10 mm. Kerang yang berumur muda memiliki pertumbuhan yang cepat dan seiring dengan pertambahan umur, ketika mencapai umur tua maka laju pertumbuhannya akan lambat bahkan cenderung statis (tetap).

Perbedaan panjang infiniti dan nilai $\mathrm{K}$ dapat disebabkan oleh kondisi perairan yang berbeda serta faktor genetik suatu biota. Perbedaan panjang asimtotik dan koefisien berbeda-beda tergantung kondisi perairan dan faktor genetik. Sparre dan Venema (1999) dalam Dewi dkk. (2015) menyatakan bahwa nilai koefisien pertumbuhan dan nilai panjang asimtotik berbeda disebabkan karena adanya perbedaan genetik serta kondisi perairan yang berbeda. Hal ini sesuai dengan pernyataan Nasrawati dkk. (2017) bahwa pada wilayah perairan sub tropis laju pertumbuhan kerang yang berumur tua maka pertumbuhannya semakin lambat dan bahkan sudah tidak dapat lagi tumbuh karena sudah mencapai panjang maksimum. Nuraini dkk. (2014) bahwa nilai pada ukuran panjang maksimum untuk kerang kepah (Meretrix meretrix) merupakan pertumbuhan maksimal yang sudah tidak memungkinkan untuk tumbuh atau bertambah panjang lagi, jika terdapat energi berlebih maka energi tersebut digunakan untuk reproduksi maupun perbaikan sel-sel yang rusak.
Pertumbuhan ini sangat ditentukan oleh koefisien pertumbuhan $(\mathrm{K})$, karena apabila nilai koefisien rendah maka dapat mempengaruhi kecepatan pertumbuhan untuk bisa tumbuh maksimal.

\subsection{Kualitas Air}

\subsubsection{Suhu}

Perbedaan suhu disetiap perairan berbeda-beda tergantung daerah dan kondisi iklim. Suhu yang terukur dalam penelitian ini adalah suhu air permukaan yang dipengaruhi intensitas sinar matahari. Tamsar dkk. (2013) menjelaskan bahwa perairan pantai daerah tropik biasanya mempunyai kisaran suhu antara 27-30 ${ }^{\circ} \mathrm{C}$ akan tetapi akan lebih tinggi dengan berkurangnya kedalaman air. Hal ini sejalan dengan pernyataan Tamsar dkk. (2013) menyatakan bahwa suhu memberikan pengaruh tidak langsung terhadap kehidupan bivalvia. Bivalvia dapat mati bila kehabisan air yang disebabkan oleh meningkatnya suhu.

\subsection{2. $\mathrm{pH}$}

Menurut Niswari (2004) bahwa salinitas juga berpengaruh pada pertumbuhan kerang, dimana pada wilayah perairan yang salinitasnya rendah maka kerang cenderung memiliki ukuran cangkang yang lebih pendek bila dibandingkan dengan kerang yang hidup pada wilayah yang bersalinitas tinggi. Nilai salinitas yang diperoleh dari hasil penelitian yang dilakukan masih dalam kondisi baik pada pertumbuhan bivalvia. Hal ini sejalan dengan pernyataan Akbar dkk. (2014) yang menyatakan bahwa sebagian besar bivalvia dapat hidup dengan baik pada kisaran salinitas 5-35\%.

\subsubsection{Salinitas}

Sebagian besar biota akuatik sensitif terhadap perubahan $\mathrm{pH}$. Nilai $\mathrm{pH}$ disetiap bulan merupakan nilai yg ideal bagi kehidupan kerang kepah. Melinda dkk. (2015) menyatakan bahwa kisaran nilai $\mathrm{pH}$ yang disukai biota akuatik adalah antara 7 - 8.5. $\mathrm{pH}$ dapat mempengaruhi daya adaptasi biota akuatik dan aktivitas kimiawi di lingkungan perairan. Hal ini sejalan dengan pernyataan Akbar dkk. (2014) yang menyatakan bahwa nilai $\mathrm{pH}$ yang berkisar antara $7-8,5$ merupakan nilai yang baik untuk pertumbuhan molusca, krustase, dan mangrove. 


\section{Simpulan dan Saran}

\subsection{Simpulan}

Dari hasil penelitian diperoleh kesimpulan adalah sebaran frekuensi panjang kerang kepah ( $M$. meretrix) di Kampung Nipah berkisar antara 14 40,35 mm, populasi kerang kepah (M. meretrix) terdiri dari satu kelompok umur dengan parameter pertumbuhan Von Bertalanffy $\mathrm{Lt}=33,1$ (1-e[-1,21 $(t+0,12])$. Hasil analisis didapatkan nilai ukuran panjang infiniti $(L \infty) 33,10 \mathrm{~mm}$ dan koefisien pertumbuhan (K) 1,21. Ukuran ini memperlihatkan bahwa pertumbuhan cangkang kerang kepah sudah tidak dapat dicapai lagi, kelompok umur Kelompok ukuran kerang kepah (M. meretrix) hanya ditemukan satu kelompok ukuran.

\subsection{Saran}

Berdasarkan peneitian yang diperoleh beberapa saran untuk penelitian selanjutnya adalah diperlukan penelitian lebih lanjut mengenai mortalitas dan laju eksploitasi, agar keberadaan kerang kepah di Kampung Nipah dapat berkelanjutan dan pemanfaatan sumberdaya hayati ikan dilakukan dengan maksimal dan responsibility, diharapkan ada tindakan dari berbagai instasi mengenai potensi kerang kepah ini karena kepah memiliki nilai ekonomis yang tinggi, sebagai khas dari Kampung Nipah dan sangat digemari oleh berbagai kalangan masyarakat sehingga keberadaan kepah di Kampung Nipah Desa Sei Nagalawan dapat berkelanjutan.

\section{Daftar Pustaka}

Akbar, J., Bahtiar, B., \& Ishak, E. (2014). Studi Morfometrik Kerang Kalandue (Polymesoda erosa) di Hutan Mangrove Teluk Kendari. Jurnal Mina Laut Indonesia, 4(1), 1-12.

Bahtiar, B., Hamzah, M., \& Hari, H. (2015). Studi Struktur dan Pertumbuhan Populasi Kerang Pokea (Batissa violacea var. celebensis, von Martens 1897) di Sungai Pohara Sulawesi Tenggara. Jurnal Biologi Tropis, 15(2), 112-124.

Bahtiar, B., Anadi, L., Nurgayah, W., Emiyarti, E., \& Hari, H. (2016). Pertumbuhan, kematian dan tingkat eksploitasi kerang pokea (Batissa violacea var. celebensis, von martens 1897) pada segmen muara Sungai Lasolo Sulawesi Tenggara. Marine Fisheries: Jurnal Teknologi dan Manajemen Perikanan Laut, 7(2), 137-147.
Fauzi, M., \& Rusliadi, R. (2011). Studi distribusi dan eksplotasi siput gonggong (Strombus turturella) di lokasi COREMAP II Kabupaten Lingga. Laporan Penelitian. Pekanbaru, Indonesia: Fakultas Perikanan Dan Ilmu Kelautan, Universitas Riau.

Dewi, K., Barus, T. A., \& Desrita, D. (2015). Analisis Pertumbuhan dan Laju Eksploitasi Ikan Tongkol (Auxis thazard) yang Didaratkan di KUD Gabion Pelabuhan Perikanan Samudera Belawan Sumatera Utara. Jurnal Aquacoastmarine, 10(5), 149-159.

Effendie, M. I. (1997). Biologi perikanan. Yogyakarta, Indonesia: Yayasan Pustaka Nusantara.

Komala, R., Yulianda, F., Lumbanbatu, D. T. F., \& Setyobudiandi, I. (2011). Morfometrik kerang Anadara granosa dan Anadara antiquata pada wilayah yang terekploitasi di Teluk Lada Perairan Selat Sunda. Jurnal Pertanian-UMMI, 1(1), 14-18.

Melinda, M., Sari, S. P., \& Rosalina, D. (2015). Kebiasaan Makan Kerang Kepah (Polymesoda erosa) di Kawasan Mangrove Pantai Pasir Padi. Jurnal Oseatek, 9(1), 35-44.

MNLH. (2001). Keputusan Menteri Negara Lingkungan Hidup Nomor 51 Tahun 2004 tentang baku mutu air laut. Jakarta-Indonesia: Menteri Negara Lingkungan Hidup.

Nasrawati, N, Bahtiar, B., \& Anadi, L. (2017). Pertumbuhan Kematian dan Tingkat Eksploitasi Kerang Coklat (Modiolus modulaides) di Perairan Teluk Kendari Sulawesi Tenggara. Jurnal Sains dan Inovasi Perikanan, 1(2), 29-36.

Niswari, A. P. (2004). Studi Morfometrik Kerang Hijau (Perna viridis, L.) di Perairan Cilincing, Jakarta Utara. Skripsi. Bogor, Indonesia: Program Studi Ilmu Kelautan, Departemen Ilmu Dan Teknologi Kelautan, Fakultas Perikanan Dan Ilmu Kelautan, Institut Pertanian Bogor.

Nuraini, N., Zulfikar, A., \& Raza'i, T. S. (2014). Kajian Stok kerang Darah (Anadara granosa) berbasis Panjang Berat yang Didaratkan di Daerah Kolong Kabupaten Karimun. Tanjungpinang, Indonesia: Jurusan Manajemen Sumberdaya Perairan, Fakultas Ilmu Kelautan dan Perikanan, Universitas Maritim Raja Ali Haji.

Siamtupang, L. L. O., Kardhinata, E. H., \& Amrul, H. M. Z. N. (2017). Keanekaragaman jenis makrozoobentos di muara Sungai Nipah Kecamatan Perbaungan Kabupaten Serdang Bedagai Sumatera Utara. BioLink (Jurnal Biologi Lingkungan, Industri, Kesehatan), 4(1), 69-81.

Sparre, P., \& Venema, S. C. (1999). Introduction to tropical fish stock assessment - Part 1: Manual. Dalam Widodo, J., Merta, I. G. S., Nurhakim, S., \& Badrudin, M. (Terj.), Introduksi pengkajian stok ikan tropis - Buku 1: Manual. Jakarta, Indonesia: Pusat Penelitian dan Pengembangan Perikanan. (Buku asli diterbitkan 1998). 
Tamsar, T., Emiyarti, E., \& Nurgayah, W. (2013). Studi laju pertumbuhan dan tingkat eksploitasi kerang kalandue (Polymesoda erosa) pada daerah hutan mangrove di Teluk Kendari. Jurnal Mina Laut Indonesia, 2(6), 14-25.

Waris, R. W. N., Zen, L. W., \& Zulfikar, A. (2014. Kajian stok siput gonggong (Strombus canarium) Perairan Madong Kota Tanjungpinang Provinsi Kepulauan Riau.
Tanjungpinang, Indonesia: Jurusan Manajemen Sumberdaya Perairan, Fakultas Ilmu Kelautan dan Perikanan, Universitas Maritim Raja Ali Haji.

Wiharyanto, D., Salim, G., Firdaus, M., \& Awaluddin, M. Y. (2013). Pendekatan metode von bertalanffy untuk analisis pertumbuhan kerang kapah (Meretrix meretrix) yang berasal dari pengepul pantai amal lama Kota Tarakan. Jurnal Akuatika, 4(1), 102-114.

(c) 2017 by the authors; licensee Udayana University, Indonesia. This article is an open access article distributed under the terms and conditions of the Creative Commons Attribution license (http://creativecommons.org/licenses/by/3.0/). 